\title{
KARAKTERISASI MUTU GELATIN YANG DIPRODUKSI DARI TULANG IKAN PATIN (Pangasius hypopthalmus) SECARA EKSTRAKSI ASAM
}

\author{
Rosmawaty Peranginangin, Mulyasari, Abdul Sari, dan Tazwir')
}

\begin{abstract}
ABSTRAK
Mutu gelatin yang diproduksi dari tulang ikan patin (Pangasius hypopthalmus) dengan cara perendaman tulang ikan patin dalam $\mathrm{HCl}$ pada $\mathrm{pH} 0,37$ yang kemudian dicuci dan diekstraksi pada suhu $90^{\circ} \mathrm{C}$ selama 7 jam dan filtratnya dikeringkan dalam oven suhu $50^{\circ} \mathrm{C}$ selama $36-48$ jam telah dikarakterisasi. Hasil karakterisasi menunjukkan bahwa rendemen $15,38 \%$ dengan kadar air $9,26 \%$, kadar abu $2,26 \%$, kadar protein $85,91 \%$, dan kandungan kalsium $57,5 \mathrm{mg} / 100 \mathrm{~g}$ Hasil pengujian Escherichia coli dan Salmonella adalah negatif. Sedangkan pengujian organoleptik menunjukkan bahwa berdasarkan penilaian panelis gelatin mempunyai nilai bau yang sama dengan standar tetapi nilai penampakan dan warnanya lebih rendah dari gelatin standar dan komersial.
\end{abstract}

ABSTRACT: Characterization of gelatin produced from catfish (Pangasius hypopthalmus) bone by acid extraction. By: Rosmawaty Peranginangin, Mulyasari, Abdul Sari, and Tazwir

Characterization of gelatin quality produced from catfish (Pangasius hypopthalmus) bone by dipping process in $\mathrm{HCl}$ solution at $\mathrm{pH} 0.37$ followed by cooking for 7 hours at $90^{\circ} \mathrm{C}$ and filtering, then drying the filtrate at $50^{\circ} \mathrm{C}$ for $36-48$ hours had been conducted. Result of the experiment revealed that the yield was $15.38 \%$, while the water, ash, protein and calcium contents were $9.26 \%, 2.26 \%$, $85.91 \%$, and $57.5 \mathrm{mg} / 100 \mathrm{~g}$ respectively. Escherichia coli and Salmonella test gave negative result but from organoleptic test panelist agree that gelatin from catfish bone had lower appearance and colour than commercial and standard gelatin although the odor was similar to standard gelatin.

KEYWORDS: gelatin, bone fish, acid extraction, characterization

\section{PENDAHULUAN}

Gelatin adalah suatu bahan tambahan protein murni yang diperoleh dari hidrolisis kolagen. Gelatin terbagi menjadi dua tipe berdasarkan perbedaan proses pengolahannya, yaitu tipe A dan tipe B. Dalam pembuatan gelatin tipe $A$, bahan baku diberi perlakuan perendaman dalam larutan asam sehingga proses ini dikenal dengan proses asam. Sedangkan dalam pembuatan gelatin tipe $B$, perlakuan yang diberikan adalah perendaman dalam larutan basa. Proses ini disebut dengan proses alkali (Utama, 1997; Anon., 2002). Perlakuan dengan proses asam akan menghasilkan gelatin dengan titik isoelektrik $\mathrm{pH} 6$ dan 9 yang menyebabkan muatan total positif sesuai untuk penggunaan dalam pangan.

Bahan baku yang berasal dari ikan biasanya diproses dengan tipe $A$ (Wiyono, 2001). Proses asam lebih disukai dibandingkan proses basa, karena pembuatan gelatin dengan proses asam memerlukan waktu yang relatif singkat dibandingkan proses basa. Gelatin mengandung 19 asam amino yang dihubungkan dengan ikatan peptida membentuk rantai polimer panjang (Glicksman, 1969). Senyawa gelatin merupakan suatu polimer linier yang tersusun oleh satuan berulang asam amino glisin-prolin atau glisinhidroksiprolin (Anon., 2002). Susunan asam amino gelatin hampir mirip dengan kolagen, dimana glisin merupakan asam amino yang utama (Charley, 1982). Penggunaan gelatin dalam pengolahan pangan lebih banyak disebabkan oleh sifat fisik dan kimia gelatin yang khas dan juga karena nutrisinya yang mengandung protein, rendah kalori dan bebas dari kolesterol. Asam amino yang ditemukan pada gelatin tidak lengkap, yaitu tidak terdapat asam amino triptofan (Fernandez et al., 2001; Anon., 2002).

Dalam industri pangan gelatin dapat berfungsi sebagai pembentuk gel, pemantap emulsi, pengental, pengikat air, pelapis, dan pengemulsi. Gelatin sebagai pelindung koloid dapat berguna dalam industri fotografi dan pelapisan logam dalam industri electroplating. Gelatin memiliki sifat dapat berubah secara reversible dari bentuk sol ke gel, atau sebaliknya, juga dapat membengkak atau mengembang dalam air dingin (Yoshimura et al., 2000). Sifat-sifat yang dimiliki gelatin tersebut membuat gelatin lebih disukai

-) Peneliti pada Pusat Riset Pengolahan Produk dan Sosial Ekonomi Kelautan dan Perikanan 
dibandingkan bahan-bahan pembentuk gel lainnya seperti gum xantan, karaginan, dan pektin (Utama, 1997).

Banyak persyaratan mutu gelatin yang diberikan oleh industri dan hal ini ditentukan oleh penggunaan bahan gelatin tersebut. Untuk tujuan pemakaian dalam bidang farmasi misalnya pembuatan kapsul keras dan kapsul lunak juga mempunyai persyaratan kekuatan gel dan viskositas yang berbeda. Demikian juga dengan pemakaian dalam produk pangan. Pada awalnya persyaratan utama dari gelatin adalah kekuatan gel kemudian diikuti oleh persyaratan viskositas, kemudian berkembang dengan persyaratan lainnya seperti kimia dan mikrobiologi. Nilai komersial gelatin semakin tinggi dengan semakin tingginya kekuatan gel dan viskositasnya (Wainewright, 1977).

Karakteristik kimia dan teknis dari gelatin merefleksikan suhu lingkungan asal dari setiap spesies (Arnesen \& Gildberg, 2002). Umumnya kolagen dari spesies yang berasal dari lingkungan temperatur rendah mempunyai kandungan asam amino (proline dan hydroxyproline) yang lebih rendah dari spesies yang hidup pada temperatur tinggi. Dengan demikian gelatin yang diproduksi dari kolagen temperatur rendah mempunyai sejumlah ikatan hidrogen yang rendah dalam larutan air dan titik leleh yang lebih rendah dibandingkan dengan gelatin yang dibuat dari spesies ikan dari lingkungan temperatur tinggi atau dari mamalia (Choi \& Regenstein, 2000, Yoshimura et al., 2000).

Dalam penelitian ini dilakukan karakterisasi mutu gelatin yang diproduksi dari tulang ikan patin secara asam untuk mengetahui kemungkinan penggunaannya sebagai bahan baku untuk pangan dan farmasi.

\section{BAHAN DAN METODE}

\section{Bahan}

Bahan utama adalah tulang ikan patin (Pangasius hypopthalmus) yang diperoleh dari limbah pengolahan fillet dari Departemen Budidaya Perairan, Fakultas Perikanan dan IImu Kelautan, Institut Pertanian Bogor. Tulang ikan segar disimpan dalam cool box yang diberi es lalu dibawa ke Pusat Riset Pengolahan Produk dan Sosial Ekonomi Kelautan dan Perikanan di Jakarta untuk diproses lebih lanjut.

Bahan-bahan lain yang digunakan sebagai pembanding gelatin yang dihasilkan adalah gelatin pangan terbuat dari sapi yang dijual secara komersial yang kemudian disebut sebagai gelatin komersial dan gelatin standar tipe A dari kulit ikan perairan dingin buatan SIGMA yang diperuntukkan khusus R\&D bukan untuk pangan. Bahan lain yang digunakan adalah $\mathrm{HCl}$ pekat untuk larutan perendaman tulang ikan, dan $\mathrm{NaOH} 0,1 \mathrm{M}$ untuk netralisasi larutan.

\section{Metode}

Tulang ikan patin dicuci dengan air bersih untuk selanjutnya dilakukan perebusan untuk degreasing yaitu menghilangan lemak serta kotoran lain yang menempel pada tulang. Perebusan ini dilakukan selama 25 menit pada suhu $80^{\circ} \mathrm{C}$. Tulang yang sudah direbus kemudian dijemur di bawah sinar matahari selama tiga hari sehingga kering. Bahan ini disimpan dalam suhu kamar dan digunakan sebagai bahan baku untuk ekstraksi gelatin.

Tulang ikan yang telah bersih dipotong-potong $1,5-2 \mathrm{~cm}$. Kemudian tulang ikan dilakukan demineralisasi sehingga diperoleh ossein, yaitu tulang yang sudah menjadi lunak. Demineralisasi dilakukan dengan merendam tulang dalam larutan $\mathrm{HCl}$ pH 0,37 selama 24 jam dengan perbandingan 1:4 (w/v). Tulang kemudian dicuci dengan air mengalir sampai tercapai pH 6-7. Kemudian dilakukan ekstraksi yaitu proses konversi kolagen menjadi gelatin. Pada proses ekstraksi perbandingan antara ossein dengan air pengekstrak (aquades) adalah 1:3 (w/v). Suhu yang digunakan adalah $90^{\circ} \mathrm{C}$ serta lama ekstraksi 7 jam. Hasil ekstraksi disaring menggunakan kapas dan kain saring blacu, kemudian filtrat dituang ke dalam pan alumunium $48 \times 39 \mathrm{~cm}$ yang diberi alas plastik tahan panas High Density Polyethylene (HDPE) dengan ketebalan $0,6 \mathrm{~cm}$. Pengeringan dilakukan pada oven $50^{\circ} \mathrm{C}$ selama $36-48$ jam sehingga diperoleh gelatin berbentuk lembaran (Nurilmala, 2004).

Analisis mutu gelatin dilakukan terhadap : kadar total protein dengan metode Kjeldahl (AOAC, 1984), kadar total lemak (Apriyantono et al., 1989), kadar abu dan kadar air, kadar kalsium, titik leleh, dan titik gel (Suryaningrum \& Utomo, 2002) dan titik isoelektrik protein (Wainewright, 1977). Filtrat dianalisis kadar nitrogennya dengan metode mikro Kjeldahl (AOAC, 1984). Kadar nitrogen terlarut yang paling rendah ditentukan sebagai daerah titik isoelektrik (pl).

Analisis asam amino dilakukan dengan menggunakan HPLC (Waters Associates) dengan detektor model 440 Absorbance Detector Waters Associates (AOAC, 1984). Kondisi HPLC pada saat dilakukan analisis adalah:

$\begin{array}{ll}\text { - Temperatur kolom } & : 38^{\circ} \mathrm{C} \\ \text { - Kolom } & \begin{array}{l}: \text { pico tag } 3,9 \times 150 \mathrm{~nm} \\ \text { coulom }\end{array} \\ \text { - Kecepatan alir } & : \text { sistem gradien linier } \\ \text { - Batas tekanan } & : 3000 \mathrm{psi}\end{array}$


- Program : gradient

- Fase gerak : - Asetonitril 60\%

- Buffer natrium asetat $1 \mathrm{M}, \mathrm{pH} 5,75$

- Detektor : : UV, panjang gelombang $254 \mathrm{~nm}$

Analisis asam lemak menggunakan alat GC (Hitachi 263-50). Jenis rekorder yang digunakan adalah Hitachi D 2000 (AOAC, 1984). Analisis kadar kalsium (Apriyantono et al., 1989) dengan menggunakan AAS Perkin Elmer 2380 sehingga absorbansi atau emisi logam dapat dianalisis dan diukur pada panjang gelombang $422,7 \mathrm{~nm}$.

Analisis mikrobiologi meliputi: Escherichia coli (SNI 01-2332, 1991) dan Salmonella (SNI 01-2335, 1991).

Uji organoleptik (Soekarto \& Hubeis, 1991) yang dilakukan adalah uji pasangan berarah. Sejumlah sampel disajikan bersama dengan pembanding, kemudian sifat mutu produk yang meliputi warna, bau, dan penampakan dinilai apakah lebih baik, sama, atau kurang. Pembanding yang digunakan adalah gelatin standar dan gelatin komersial. Panelis yang menguji adalah panelis terlatih sebanyak 15 orang. Data hasil respon dari 15 orang panelis terlatih dianalisis dengan cara tabel. Tabel yang digunakan adalah tabel beda nyata pada uji segitiga dengan hipotesis berekor satu. Jika jumlah panelis 15 orang, maka untuk dinyatakan berbeda nyata, jumlah respon yang terkecil terhadap pembanding harus mencapai 9 orang pada tingkat beda nyata $5 \%$, atau mencapai 10 orang pada tingkat beda nyata $1 \%$.

\section{HASIL DAN BAHASAN}

\section{Kekuatan Gel, Viskositas dan pH Gelatin dari Tulang Ikan Patin}

Gelatin yang dihasilkan dalam penelitian ini mempunyai kekuatan gel 279,10 bloom, viskositas sebesar 4,17 cPs dan pH 4,61 (Tabel 1). Untuk gelatin sebagai bahan pangan spesifikasinya dapat dilihat pada Tabel 2 sedangkan untuk bahan farmasi pada Tabel 3. Dibandingkan dengan Tabel 2 dan 3 maka kekuatan gel gelatin yang diperoleh termasuk kelas

Tabel 1. Nilai kekuatan gel, viskositas, dan $\mathrm{pH}$ gelatin tulang ikan patin, standar dan komersial Table 1. Value of gel strength (bloom), viscosity (cPs) and pH of catfish, standard and commercial gelatin

\begin{tabular}{lccc}
\hline \multirow{2}{*}{ Parameter/ Parameters } & \multicolumn{3}{c}{ Gelatin } \\
\cline { 2 - 4 } & $\begin{array}{c}\text { Tulang ikan patin/ } \\
\text { Catfish bone }\end{array}$ & $\begin{array}{c}\text { Standarl } \\
\text { Standard }\end{array}$ & $\begin{array}{c}\text { Komersial/ } \\
\text { Commercial }\end{array}$ \\
\hline Kekuatan gel/Gel strength & 279.10 & Tidak membentuk gel/ & 328.57 \\
(Bloom) & & Not forming gel & 7.00 \\
Viskositas/Viscosity (cPs) & 4.17 & 6.00 & 5.00 \\
$\mathrm{pH}$ & 4.61 & 5.90 & \\
\hline
\end{tabular}

Tabel2. Spesifikasi gelatin pangan

Table 2. Edible gelatin specifications

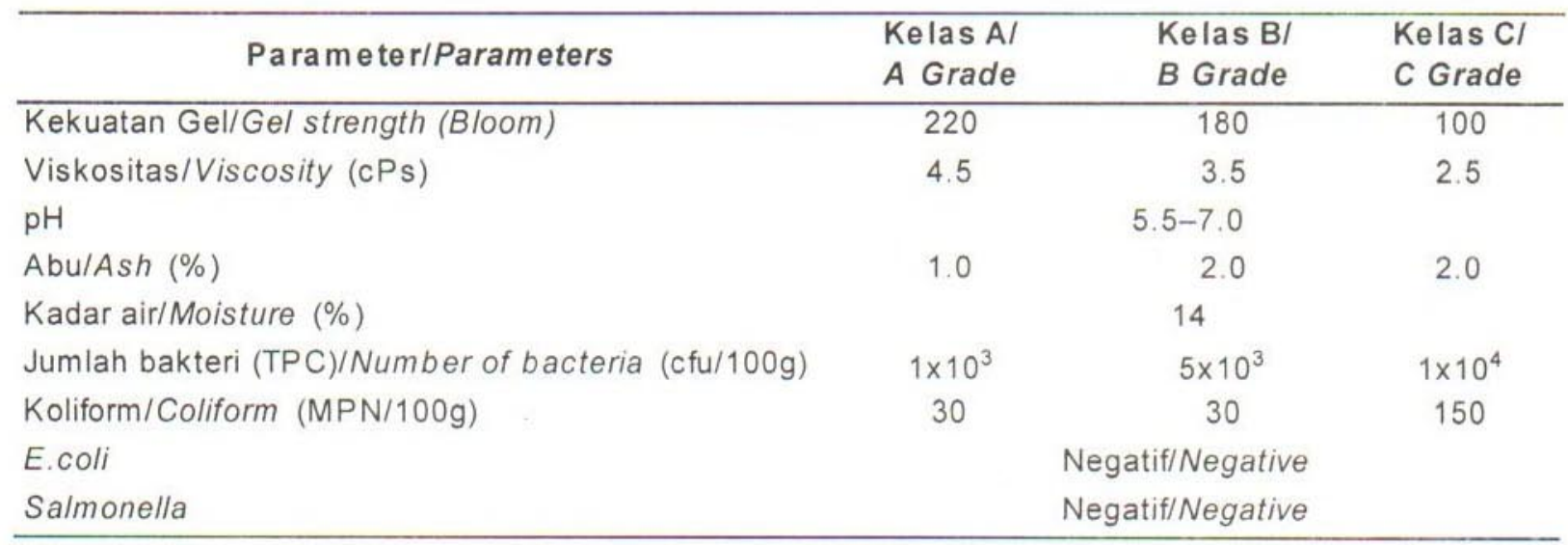


khușus yang memenuhi persyaratan sebagai bahan baku untuk pangan maupun untuk farmasi.

Hasil penelitian dari segi kekuatan gel tidak dibandingkan dengan gelatin standar karena gelatin ini dikhususkan untuk tidak menjendal pada suhu kamar maupun dingin karena digunakan untuk bahan blocking dalam immunokimia (Sigma, 2002). nila merah hanya $3,20 \mathrm{cPs}$ (Jamilah \& Harvinder, 2002).

Nilai $\mathrm{pH}$ gelatin dari tulang ikan patin $(4,61)$ lebih rendah dari $\mathrm{pH}$ standar $(5,9)$ dan $\mathrm{pH}$ gelatin komersial $(5,0)$. Dengan demikian gelatin tulang ikan patin memenuhi kriteria sebagai bahan pangan $(\mathrm{pH} 4,5)$ tetapi tidak memenuhi untuk farmasi $(\mathrm{pH} 5,5-7,0)$.

Tabel 3. Spesifikasi gelatin untuk farmasi

Table 3. Pharmaceutical gelatin specifications

\begin{tabular}{|c|c|c|c|c|}
\hline Parameter/Parameters & $\begin{array}{l}\text { Kelas khusus/ } \\
\text { Special class }\end{array}$ & $\begin{array}{l}\text { Mutu kesatul } \\
\text { First class }\end{array}$ & $\begin{array}{l}\text { Mutu kedua/ } \\
\text { Second class }\end{array}$ & $\begin{array}{l}\text { Mutu ketiga/ } \\
\text { Third class }\end{array}$ \\
\hline Kadar air/Moisture content (\%) & 14.0 & 14.0 & 14.0 & 14.0 \\
\hline Kekuatan gel/Gel strength (Bloom) & 240 & 200 & 160 & 140 \\
\hline Viskositas/Viscosity (cPs) & 4.7 & 4.2 & 3.7 & 3.2 \\
\hline Abu/Ash $(\%)$ & 1.0 & 1.0 & 2.0 & 2.0 \\
\hline $\mathrm{pH}$ & \multicolumn{4}{|c|}{$5.5-7.0$} \\
\hline Mikrobiologi/Microbiology (cfu/100 g) & \multicolumn{4}{|c|}{$\leqslant 10^{3}$} \\
\hline E. coli/100 g & \multicolumn{4}{|c|}{ Negatif/Negative } \\
\hline Salmonella & \multicolumn{4}{|c|}{ Negatif/Negative } \\
\hline
\end{tabular}

Dibandingkan dengan gelatin komersial maka kekuatan gel gelatin dari tulang ikan patin masih lebih rendah. Kekuatan gel dipengaruhi oleh konsentrasi dan berat molekul, dalam penelitian ini belum dilakukan pemisahan berat molekul yang besar dan kecil yang dapat dilakukan secara dialisis, yang diperoleh hanya berat molekul yang tinggi saja sehingga kekuatan gel semakin tinggi. Perbedaan jenis bahan baku juga sangat mempengaruhi kekuatan gel, seperti pada ikan nila merah (Oreochromis mossambicus) yang mempunyai kekuatan gel 128,11 bloom dibandingkan dengan nila hitam (Oreochromis nilotica) dengan kekuatan gel 180,76 bloom (Jamilah \& Harvinder, 2002) maka kekuatan gel dari tulang ikan patin masih lebih tinggi $(279,10$ bloom $)$.

Viskositas gelatin dari hasil penelitian ini adalah 4,17 cPs sehingga dapat dimasukkan dalam kelas B (Tabel 2) untuk mutu pangan dan tergolong kelas kedua sebagai mutu farmasi (Tabel 3). Dibandingkan dengan gelatin komersial yang mempunyai viskositas $7 \mathrm{cPs}$ dan gelatin standar $6 \mathrm{cPs}$ maka viskositas gelatin dari tulang ikan patin tergolong di bawah mutu gelatin standar dan komersial. Meskipun demikian hasil yang diperoleh sudah mendekati gelatin kelas satu $(4,2 \mathrm{cPs})$ sedangkan viskositas dari gelatin ikan
Rendahnya $\mathrm{pH}$ gelatin disebabkan karena $\mathrm{pH}$ yang digunakan untuk pembentukan ossein adalah 0,37 dan pada waktu netralisasi masih kurang sehingga $\mathrm{pH}$ gelatin masih terlalu rendah.

\section{Komposisi Proksimat Gelatin}

Komposisi proksimat gelatin tulang ikan patin yang dihasilkan dalam penelitian ini disajikan dalam Tabel 4. Sebagai pembanding disajikan gelatin tulang ikan pari yang merupakan tulang ikan rawan (elasmobranch) berdasarkan penelitian Sopian (2002) yang diekstraksi secara asam. Analisis kadar air dilakukan untuk mengetahui kandungan air dalam gelatin tulang yang dibandingkan dengan gelatin standar dan gelatin komersial. Kadar air sangat berpengaruh terhadap mutu bahan pangan. Air dapat mempengaruhi penampakan, tekstur, serta cita rasa bahan makanan, serta berpengaruh dalam penyimpanan (Winarno, 1991).

Kadar air gelatin tulang ikan patin (Tabel 4) lebih rendah dibandingkan dengan kadar air gelatin standar dan gelatin komersial. Akan tetapi kadar air gelatin tulang ikan pari (elasmobranch) lebih rendah dibandingkan yang lainnya $(5,10 \%)$. Kadar air gelatin tulang ikan patin yang dihasilkan pada 
Tabel 4. Hasil analisis proksimat gelatin tulang ikan patin tipe $A$

Table 4. Proximate analysis of gelatin from catfish bone type $A$

\begin{tabular}{|c|c|c|c|c|c|}
\hline $\begin{array}{l}\text { Parameter/ } \\
\text { Parameters }\end{array}$ & $\begin{array}{c}\text { Gelatin tulang } \\
\text { ikan patin/ } \\
\text { Catfish bone } \\
\text { gelatin }\end{array}$ & $\begin{array}{c}\text { Gelatin } \\
\text { komersial/ } \\
\text { Commercial } \\
\text { gelatin }\end{array}$ & $\begin{array}{c}\text { Gelatin tulang } \\
\text { ikan pari/ } \\
\text { Sting rays } \\
\text { bone gelatin }\end{array}$ & $\begin{array}{c}\text { Standar SNI 06- } \\
3735(1995) / \\
\text { SNI 06-3735 } \\
\text { Standard (1995) }\end{array}$ & $\begin{array}{c}\text { Gelatin } \\
\text { standarl } \\
\text { Standard } \\
\text { gelatin }\end{array}$ \\
\hline $\begin{array}{l}\text { Kadar air }(\%) \text { I } \\
\text { Moisture content (\%) }\end{array}$ & 9.60 & 12.20 & 5.10 & Maksimum 16 & 11.45 \\
\hline $\begin{array}{l}\text { Kadar abu }(\%) / \\
\text { Ash content (\%) }\end{array}$ & 2.26 & 1.66 & 13.70 & Maksimum 3.25 & 0.52 \\
\hline $\begin{array}{l}\text { Kadar lemak }(\%) \text { I } \\
\text { Fat content }(\%)\end{array}$ & 1.95 & 0.23 & 0.30 & - & 0.25 \\
\hline $\begin{array}{l}\text { Kadar protein }(\%) / \\
\text { Protein content }(\%)\end{array}$ & 85.91 & 85.99 & 66.10 & - & 87.26 \\
\hline
\end{tabular}

Sumber/Sources: Sopian (2002)

penelitian ini sebesar $9,26 \%$ yang berarti masih memenuhi standar SNI (1995) yaitu maksimum 16\% maupun standar pangan (14\%) dan farmasi $(14 \%)$.

Hasil pengukuran kadar abu gelatin tulang ikan patin adalah $2,26 \%$. Kadar ini masih memenuhi ketetapan SNI (1995) yaitu sebesar 3,25\%, akan tetapi tidak memenuhi standar sebagai bahan pangan dan farmasi yaitu kurang dari atau sama dengan $2 \%$ (Tabel 2 dan 3). Sedangkan kadar abu gelatin tulang ikan pari (elasmobranch) sangat tinggi $(13,70 \%)$, hal ini menurut Sopian (2002) disebabkan karena serbuk ossein masih banyak yang terbawa pada saat penyaringan.

Kadar lemak gelatin tulang ikan patin yang dihasilkan dalam penelitian (1,95\%) adalah lebih besar dari gelatin komersial $(0,23 \%)$, sehingga masih memerlukan penelitian bagaimana mengurangi kandungan lemak dari bahan baku yang digunakan.
Hasil penelitian kadar total protein antara gelatin tulang ikan patin $(85,91 \%)$ tidak jauh berbeda dengan kadar protein gelatin komersial $(85,99 \%)$ (Tabel 4), sedangkan kadar total protein gelatin tulang ikan pari (elasmobranch) hanya $66,10 \%$. Rendahnya kadar protein gelatin tulang ikan pari (elasmobranch) dikarenakan tingginya komponen non gelatin dalam hal ini tingginya kadar abu (Sopian, 2002).

\section{Titik Gel dan Titik Leleh Gelatin}

Hasil analisis titik gel dan titik leleh gelatin tulang ikan patin yang dibandingkan dengan gelatin komersial dan standar dapat dilihat pada Tabel 5 .

Dari hasil pengukuran terlihat gelatin komersial mempunyai titik gel $19,5^{\circ} \mathrm{C}$, sedangkan gelatin tulang ikan patin adalah $8,2^{\circ} \mathrm{C}$ dan gelatin standar $1,30^{\circ} \mathrm{C}$. Titik gel adalah suhu dimana gelatin mulai membentuk gel (Suryaningrum \& Utomo, 2002). Gelatin yang

Tabel 5. Hasil pengukuran titik gel dan titik leleh gelatin

Table 5. Gelling and melting points of gelatin

\begin{tabular}{lcc}
\hline \multicolumn{1}{c}{ Sampel/Sample } & $\begin{array}{r}\text { Titik gel }\left({ }^{\circ} \mathrm{C}\right) / \\
\text { Gelling point }\left({ }^{\circ} \mathrm{C}\right)\end{array}$ & $\begin{array}{c}\text { Titik leleh }\left({ }^{\circ} \mathrm{C}\right) / \\
\text { Melting point }\left({ }^{\circ} \mathrm{C}\right)\end{array}$ \\
\hline $\begin{array}{l}\text { Gelatin komersial/ } \\
\text { Commercial gelatin }\end{array}$ & 19.50 & 29.60 \\
$\begin{array}{l}\text { Gelatin tulang ikan patin/ } \\
\text { Catfish bone gelatin }\end{array}$ & 8.20 & 24.00 \\
$\begin{array}{l}\text { Gelatin standar/ } \\
\text { Standard gelatin }\end{array}$ & 1.30 & 16.30 \\
\hline
\end{tabular}


beraşal dari ikan mempunyai titik gel yang jauh lebih rendah dibandingkan dengan mamalia (gelatin komersial). Gelatin standar mempunyai titik gel yang sangat rendah karena berasal dari ikan dari daerah dingin.

Hasil pengukuran titik leleh gelatin tulang ikan patin adalah $24,0^{\circ} \mathrm{C}$. Sedangkan gelatin komersial $29,6^{\circ} \mathrm{C}$ dan gelatin standar $16,30^{\circ} \mathrm{C}$ (Tabel 5). Titik leleh adalah suhu dimana gelatin mulai meleleh (mencair). Produk gelatin adalah produk yang pada suhu $<35^{\circ} \mathrm{C}$ sudah mengalami pelelehan dan dapat mencair dalam mulut (Anon., 2002). Dari hasil penelitian ini berarti gelatin dapat membentuk gel pada suhu $8,2^{\circ} \mathrm{C}$ dan mencair pada suhu $24,0^{\circ} \mathrm{C}$, dan ini merupakan sifat yang baik untuk dijadikan sebagai bahan baku untuk pangan yang memerlukan titik leleh yang rendah. Titik gel dan titik leleh dari gelatin yang terbuat dari ikan terbukti lebih rendah dari gelatin mamalia (komersial). Hal ini disebabkan karena stabilitas struktur dari gelatin ikan lebih lemah dibandingkan dengan gelatin mamalia (Yoshimura et al., 2000).

Tabel6. Hasil analisis asam amino gelatin

Table 6. Amino acids composition of gelatin

\section{Asam Amino Gelatin}

Hasil analisis asam amino dari gelatin tulang ikan patin, gelatin standar dan komersial disajikan pada Tabel 6. Berdasarkan analisis proksimat, kadar total protein gelatin tulang ikan patin adalah $85,91 \%$, gelatin komersial $85,99 \%$ dan gelatin standar adalah $87,26 \%$ (Tabel 4).

Gelatin adalah protein yang mempunyai nilai gizi rendah, karena pada gelatin tidak terkandung seluruh asam amino esensial pembentuk protein secara lengkap. Gelatin merupakan suatu protein yang tidak mengandung asam amino triptofan (Anon., 2002). Oleh karena itu gelatin lebih banyak digunakan atas pertimbangan sifat fisika kimianya daripada nilai gizinya.

Dari hasil pengukuran terlihat kandungan glisin lebih tinggi dibandingkan asam amino lainnya (Tabel 6). Hal ini sesuai dengan yang dikemukakan Charley (1982) bahwa susunan asam amino gelatin hampir mirip dengan kolagen; glisin merupakan asam amino

\begin{tabular}{|c|c|c|c|c|}
\hline \multirow[b]{2}{*}{ No } & \multirow[b]{2}{*}{$\begin{array}{l}\text { Jenis a sam aminolkind of amino } \\
\text { acids }\end{array}$} & \multicolumn{3}{|c|}{ Konsentrasi/Concentration ( $\mathrm{g} / 100 \mathrm{~g}$ protein) } \\
\hline & & $\begin{array}{c}\text { Gelatin tulang } \\
\text { ikan patin/ } \\
\text { Catfish bone } \\
\text { gelatin }\end{array}$ & $\begin{array}{c}\text { Gelatin } \\
\text { standarl } \\
\text { Standard } \\
\text { gelatin }\end{array}$ & $\begin{array}{c}\text { Gelatin } \\
\text { komersial/ } \\
\text { Commercial } \\
\text { gelatin }\end{array}$ \\
\hline \multicolumn{5}{|c|}{ Asam amino esensial/Essential amino acids } \\
\hline 1 & Isoleusin/lsoleucine & 1.07 & 1.03 & 1.13 \\
\hline 2 & Leusin/Leucine & $\begin{array}{l}\text { Tidak terdeteksi/ } \\
\text { Not detected }\end{array}$ & $\begin{array}{l}\text { Tidak terdeteksi/ } \\
\text { Not detected }\end{array}$ & $\begin{array}{l}\text { Tidak terdeteksi/ } \\
\text { Not detected }\end{array}$ \\
\hline 3 & Arginin/Arginine & 8.23 & 8.12 & 8.95 \\
\hline 4 & Lisin/Lysine & 1.89 & 1.53 & 2.86 \\
\hline 5 & Tirosin/Tyrosine & 0.09 & 0.11 & 0.15 \\
\hline 6 & Histidin/Histidine & 0.01 & 0.02 & 0.03 \\
\hline 7 & Valin/Valine & 1.34 & 1.25 & 1.60 \\
\hline 8 & Metionin/Methionine & 0.37 & 0.42 & 0.55 \\
\hline 10 & Fenilalanin/ Phenylalanine & 2.01 & 1.96 & 1.92 \\
\hline 11 & Treonin/Threonine & 2.55 & 2.93 & 2.87 \\
\hline \multicolumn{5}{|c|}{ Asam amino bukan esensial/Non essential amino acids } \\
\hline 1 & Glisin/Glycine & 22.97 & 23.18 & 23.01 \\
\hline 2 & Prolin/Proline & 12.17 & 12.54 & 12.34 \\
\hline 3 & Hidroksiprolin/ Hydroxyproline & 6.25 & 8.85 & 8.74 \\
\hline 4 & Alanin/Alanine & 10.31 & 10.07 & 10.24 \\
\hline 5 & Asam aspartat/Aspartic acid & 4.53 & 5.15 & 4.93 \\
\hline 6 & Serin/Serine & 2.00 & 1.97 & 2.18 \\
\hline 7 & Asam glutamat/Glutamic acid & 9.30 & 9.47 & 9.43 \\
\hline 8 & Sistein/Cysteine & 0.06 & 0.10 & 0.07 \\
\hline
\end{tabular}


yang utama. Tingginya kandungan glisin pada gelatin diduga dapat menyebabkan gelatin mudah larut dalam air, karena asam amino glisin merupakan asam amino yang hidrofilik.

Asam amino hidroksiprolin adalah asam amino yang khas yang ditemukan pada kolagen (Lehninger, 1982; Chasanah, 2000). Susunan asam amino pada kolagen adalah mirip seperti gelatin. Dari hasil analisis terlihat bahwa jumlah dan komposisi asam amino gelatin tulang ikan patin tidak jauh berbeda dengan gelatin standar maupun gelatin komersial. Glisin merupakan asam amino yang tertinggi yaitu pada gelatin tulang ikan patin sebesar $22,97 \mathrm{~g} / 100 \mathrm{~g}$ protein, pada gelatin standar $23,18 \mathrm{~g} / 100 \mathrm{~g}$ protein dan pada gelatin komersial adalah $23,01 \mathrm{~g} / 100 \mathrm{~g}$ protein. Jenis asam amino kedua yang terbesar adalah hidroksiprolin yaitu $12,17 \mathrm{~g} / 100 \mathrm{~g}$ protein, $12,54 \mathrm{~g} /$ $100 \mathrm{~g}$ protein dan $12,34 \mathrm{~g} / 100 \mathrm{~g}$ protein masing-masing untuk gelatin tulang ikan patin, standar, dan komersial (Tabel6).

\section{Asam Lemak Gelatin}

Komposisi asam lemak gelatin tulang ikan patin dapat dilihat pada Tabel 7. Analisis asam lemak dilakukan karena kandungan lemak gelatin dari tulang ikan patin lebih tinggi dari gelatin standar dan komersial sehingga ingin diketahui apakah lemak ini terdiri dari asam lemak yang tidak jenuh.

Lemak yang terkandung dalam gelatin tulang ikan patin sebesar $1,95 \%$, gelatin komersial $0,23 \%$, dan gelatin standar adalah 0,25\% (Tabel 4). Lemak tersebut tersusun atas asam-asam lemak.
Pada Tabel 7 terlihat bahwa kandungan asam lemak jenuh palmitat paling tinggi di antara asam lemak jenuh lainnya. Hal ini sesuai dengan yang dikemukakan Winarno (1991) bahwa palmitat adalah asam lemak jenuh yang paling banyak ditemukan pada bahan pangan. Asam lemak linolenat gelatin tulang ikan patin adalah sebesar 1,22\% (Tabel 7). Jumlah asam lemak linolenat yang merupakan prekursor $n-3$ tersebut sangat kecil. Ikan patin (Pangasius hypopthalmus) merupakan ikan air tawar, yang mengkonsumsi jenis plankton yang hanya mengandung sedikit $n-3$.

Baik gelatin tulang ikan patin, gelatin standar, maupun gelatin komersial mengandung jumlah asam lemak tidak jenuh oleat yang tinggi. Menurut Muchtadi et al. (1992) umumnya lemak hewan banyak mengandung asam lemak tidak jenuh oleat.

\section{Kadar Kalsium Gelatin}

Hasil penelitian kadar kalsium gelatin dari tulang ikan patin dapat dilihat pada Tabel 8. Dari hasil analisis kalsium terlihat bahwa gelatin tulang ikan patin mengandung kalsium dengan jumlah yang tinggi yaitu $57,5 \mathrm{mg} / 100 \mathrm{~g}$ sedangkan gelatin standar 0 dan gelatin komersial $23,0 \mathrm{mg} / 100 \mathrm{~g}$ gelatin. Hal ini disebabkan bahan baku gelatin tulang ikan patin mempunyai kadar kalsium yang tinggi dan belum sempurna dalam demineralisasi. Akan tetapi nilai ini masih memenuhi standar yaitu kurang dari $60 \mathrm{mg} / 100 \mathrm{~g}$ (Anon., 2002).

Apabila kadar kalsium melebihi $60 \mathrm{mg} / 100 \mathrm{~g}$ maka diduga akan mempengaruhi pemanfaatannya dalam bahan pangan. Tingginya kandungan kalsium dapat

Tabel 7. Asam lemak gelatin tulang ikan patin ( $\mathrm{g} / 100 \mathrm{~g}$ lemak)

Table 7. Fatty acids of gelatin catfish bone $(\mathrm{g} / 100 \mathrm{~g}$ fat)

\begin{tabular}{lccc}
\hline \multicolumn{1}{c}{ Asam lemak/ } & $\begin{array}{c}\text { Gelatin tulang } \\
\text { Fatty acids }\end{array}$ & $\begin{array}{c}\text { Gelatin standar/ } \\
\text { bone gelatin }\end{array}$ & $\begin{array}{c}\text { Gelatin Komersial/ } \\
\text { Standard gelatin } \\
\text { Gelatin }\end{array}$ \\
\hline Jenuh/Saturated & 0.82 & 1.18 & 0.60 \\
Laurat/Lauric $\left(\mathrm{C}_{12}\right)$ & 0.57 & 1.24 & 1.59 \\
Miristat/Myristic $\left(\mathrm{C}_{14}\right)$ & 50.62 & 35.26 & 23.08 \\
Palmitat/Palmitic $\left(\mathrm{C}_{16}\right)$ & 0.71 & Tidak terdeteksi/ & 2.07 \\
Stearat/Stearic $\left(\mathrm{C}_{18}\right)$ & & Not detected & \\
& & & \\
\hline Tidak jenuh/ & 42.49 & 42.90 & 57.25 \\
Unsaturated & 3.05 & 8.44 & 1.87 \\
Oleat/Oleic $\left(\mathrm{C}_{18: 1}\right)$ & 1.22 & 4.71 & 1.35 \\
Linoleat/Linoleic $\left(\mathrm{C}_{18: 2}\right)$ & & & \\
Linolenat/Linolenic $\left(\mathrm{C}_{18: 3}\right)$ & & & \\
\hline
\end{tabular}


menyebabkan terjadinya presipitasi dengan asam dari buah-buahan, dapat juga menyebabkan kekeruhan pada jelli dan deposit warna putih yang dikenal dengan "white spol" pada permukaan jelli ayam karena adanya reaksi antara phosphat dalam ekstrak daging (Jones, 1977).

\section{Titik Isoelektrik Protein}

Hasil pengukuran titik isoelektrik protein gelatin tulang ikan patin sama dengan gelatin standar yaitu 8,0 sedangkan untuk gelatin komersial adalah 7,0 (Tabel 8). Titik isoelektrik protein yang dihasilkan pada penelitian ini tidak sesuai yang disyaratkan Tourtellote (1980) yaitu pada gelatin dengan proses asam antara $9,0-9,2$ akan tetapi sesuai dengan Poppe (1992) yaitu $7,0-9,4$.

Titik isoelektrik protein adalah $\mathrm{pH}$ dimana protein mempunyai jumlah muatan ion positif dan negatif yang sama (Lehninger, 1982). Titik isoelektrik penting untuk hendaknya melarutkan gelatin tidak pada titik isoelektriknya.

\section{Uji Mikrobiologi Gelatin}

Pengukuran Escherichia coli dan Salmonella sp., baik pada gelatin tulang ikan patin maupun gelatin standar dan gelatin komersial adalah negatif. Tidak adanya kandungan kedua jenis bakteri ini sesuai seperti yang disyaratkan dalam standar gelatin (Anon., 2003)

Adanya Escherichia coli dalam suatu bahan merupakan indikator kontaminasi kotoran (Fardiaz, 1989). Sedangkan beberapa spesies Salmonella merupakan bakteri patogen yang berbahaya. Salmonella sp. dapat menyebabkan gangguan perut, demam tifus dan paratifus (Fardiaz, 1989). Hasil penelitian ini menunjukkan bahwa gelatin yang diperoleh tidak terkontaminasi oleh kotoran manusia dan bakteri patogen sehingga aman untuk dikonsumsi.

Tabel 8. Kandungan kalsium dan titik isoelektrik protein gelatin

Table 8. Calcium content and isoelectric point of gelatin protein

\begin{tabular}{lcc}
\hline \multicolumn{1}{c}{ Sampel/Sample } & $\begin{array}{c}\text { Kalsium/ } \\
\text { Calcium (mg/100gr) }\end{array}$ & $\begin{array}{c}\text { Titik isoelektrik } \\
\text { protein/ } \\
\text { Isoelectric points of } \\
\text { protein }\end{array}$ \\
\hline Gelatin standar/Standard gelatin & 0 & 8.0 \\
Gelatin komersial/Commercial gelatin & 23.0 & 7.0 \\
Gelatin tulang ikan patin/Catfish bone gelatin & 57.5 & 8.0 \\
\hline
\end{tabular}

mengetahui kelarutan protein. Pada $\mathrm{pH}$ titik isoelektrik, kelarutan protein rendah sehingga terjadi penggumpalan atau pengendapan protein.

Titik isoelektrik protein dapat bervariasi tergantung jumlah gugus karboksilamida pada gelatin. Apabila titik isoelektrik protein tinggi $(9,4)$ maka tidak ada modifikasi terhadap gugus amida dan apabila titik isoelektriknya rendah $(4,8)$ maka $90-95 \%$ protein dari gelatin merupakan gugus karboksil (Poppe, 1992). Seperti sifat protein lainnya, gelatin bersifat amfoter (Anon., 2002), sehingga gelatin dapat digunakan pada kondisi asam maupun basa. Pada larutan asam, gelatin akan berperan sebagai alkali atau bermuatan positif, sedangkan dalam larutan basa gelatin akan

" berperan sebagai asam atau bermuatan negatif. Titik isoelektrik protein berkaitan dengan viskositas, dimana viskositas gelatin terendah diperoleh pada $\mathrm{pH}$ titik isoelektriknya (Poppe, 1992). Oleh karena itu untuk mendapatkan viskositas yang tinggi maka

\section{Uji Organoleptik Gelatin}

Hasil uji organoleptik untuk bau, penampakan dan warna gelatin disajikan pada Tabel 9. Dari segi aroma/ bau gelatin tulang ikan patin adalah lebih baik daripada gelatin standar (GS). Hal ini dinyatakan oleh lebih dari 9 orang panelis yang menyatakan respon lebih baik (Tabel 9) seperti yang disyaratkan pada tabel uji segitiga dengan hipotesis berekor satu (Soekarto \& Hubeis, 1991). Panelis menyatakan aroma/bau gelatin tulang ikan patin lebih baik daripada gelatin standar dan komersial karena bau amis tidak sekuat pada gelatin standar dan komersial.

$\mathrm{Hal}$ ini diduga karena penggunaan asam kuat pada proses pembuatan gelatin tulang ikan patin dapat mengurangi bau amis pada gelatin yang dihasilkan. Untuk perbandingan dengan gelatin komersial tidak bisa diambil kesimpulan karena kurang dari 9 orang panelis yang menyatakan hasil yang sama 
Dari hasil respon penampakan terlihat bahwa gelatin tulang ikan patin masih kurang baik di bandingkan dengan gelatin standar (GS) dan gelatin komersial (GK), karena jumlah panelis yang memberikan penilaian 'kurang' adalah lebih dari 9 orang seperti yang disyaratkan (Soekarto \& Hubeis, 1991). Hal ini karena ukuran butiran-butiran gelatin tulang ikan patin tidak seragam sehingga panelis memberikan respon kurang baik.

Pada organoleptik warna, gelatin tulang ikan patin masih kurang baik dibandingkan gelatin standar (GS) dan gelatin komersial (GK), karena jumlah panelis yang menyatakan 'kurang' dibandingkan standar adalah lebih dari 9 orang seperti yang disyaratkan (Soekarto \& Hubeis, 1991). Hal ini karena gelatin
4. Dari uji organoleptik, bau gelatin tulang ikan patin lebih baik daripada gelatin standar, akan tetapi dari segi penampakan dan warna masih kurang baik dibandingkan gelatin standar dan komersial.

\section{Saran}

Beberapa hal yang disarankan setelah dilakukannya penelitian ini adalah masih perlu dilakukan usaha dalam mengurangi kandungan lemak dan abu serta memperbaiki warna dari gelatin yang dihasilkan. Standar mutu untuk unsur yang lainnya seperti logam berat, arsen, kandungan sulfat juga perlu diperhatikan agar gelatin yang dihasilkan memenuhi persyaratan sebagai bahan baku untuk pangan dan farmasi.

Tabel 9. Hasil organoleptik terhadap aroma/bau gelatin

Table 9. Organoleptic respons of panelist on odor of gelatin

\begin{tabular}{lcccccc}
\hline $\begin{array}{c}\text { Parameter uji } \\
\text { organoleptik/ } \\
\text { Item organoleptic } \\
\text { parameters }\end{array}$ & $\begin{array}{c}\text { Jumlah orang yang } \\
\text { menyatakan kurang } \\
\text { dari standarl } \\
\text { Total of panelist } \\
\text { declared below } \\
\text { standard }\end{array}$ & $\begin{array}{c}\text { Jumlah orang yang } \\
\text { menyatakan sama } \\
\text { dengan standarl } \\
\text { Total of panelist } \\
\text { declared same with } \\
\text { standard }\end{array}$ & $\begin{array}{c}\text { Jumlah orang } \\
\text { lebih dari standarl } \\
\text { Total of panelist } \\
\text { declared above } \\
\text { standard }\end{array}$ \\
\hline Aroma/Odor & GS & GK & GS & GK & GS & GK \\
\cline { 2 - 8 } Penampakan/Appearance & 2 & 3 & 2 & 7 & 10 & 4 \\
Warna/Colour & 13 & 14 & 0 & 0 & 2 & 1 \\
\hline Keterangan/Notes: GS = gelatin standar/standard gelatin \\
GK = gelatin komersial/commercial gelatin
\end{tabular}

tulang ikan patin mempunyai warna kuning kecoklatan, sehingga panelis memberikan respon yang kurang baik.

\section{KESIMPULAN DAN SARAN}

Beberapa kesimpulan yang dapat diambil adalah:

1. Dari segi kekuatan gel, gelatin yang dihasilkan memenuhi persyaratan sebagai bahan baku untuk pangan dan farmasi dan tergolong kelas khusus sedangkan dari viskositas juga memenuhi persyaratan sebagai bahan baku farmasi dan tergolong sebagai kelas ke dua.

2. Kandungan abu memenuhi standar SNI tetapi tidak memenuhi persyaratan untuk kualitas pangan dan farmasi.

3. Dari segi uji mikrobiologi, kandungan Escherichia coli dan Salmonella pada gelatin adalah negatif.

\section{DAFTAR PUSTAKA}

AOAC. 1984. Official Methods of Analysis of Association Official Agricultural Chemist. Washington, DC.

Anonymous. 2002. Gelatin Food Science. http:// www.gelatin.co.za/gltn1.html.

Anonymous. 2003. Norland Products. http://www.norland prod.com/techrpts/fishgelrpt.html.

Apriyantono, A., Fardiaz, D., Puspitasari, N.L., Yasni, S. dan Budiyanto, S. 1989. Analisa Pangan. IPB Press. Bogor. 229 pp.

Arnesen, J.A. and Gildberg, A. 2002. Preparation and characterisation of gelatin from the skin of harp seal (Phoca groendlandica). Bioresource Technology. 82: 191-194.

Charley, H. 1982. Food Science $2^{\text {nd }}$ ed. John Wiley and Sons. New York.

Choi, S.S. and Regenstein, J.M. 2000. Physicochemical and sensory characteristics of fish gelatin. J. Food Sci. 65: 194-199. 
Chasanah, E. 2000. Acid extraction of gelatin from dried shark skin. Indonesian Food and Nutrition Progress. $7(1): 6-12$.

Fardiaz, S. 1989. Mikrobiologi Pangan. Departemen Pendidikan dan Kebudayaan. Direktorat Jenderal Pendidikan Tinggi. PAU Pangan dan Gizi. Institut Pertanian Bogor. 119 pp.

Fernandez, M.D., Montero, P., and Guillen, M.C.G. 2001. Gel properties of collagens from skins of cod ( $\mathrm{Ga}$ dus morhua) and hake (Merluccius merluccius) and their modification by the coenhancers magnesium sulphate, glycerol and transglutaminase. Food Chemistry. 74: 161-167.

Glicksman, M. 1969. Gum Technology in The Food Industry. Academic Press, New York. 590 pp.

Jamilah, B. and Harvinder, K.G. 2002. Properties of Gelatin from skons black tilapia (Oreochromis mossambicus) and red tilapia (Oreochromis nilotica). Food Chemistry 77: 81-84.

Jones, N.R. 1977. Uses of gelatin in edible products. In Ward, A.G. and Courts, A. (eds.). The Science and Technology of Gelatin. Academic Press. London. p. 365-394.

Lehninger, A.L. 1982. Dasar-dasar Biokimia Jilid I. Penerjemah M. Thenawijaya. Erlangga, Jakarta. 369 pp.

Muchtadi, D., Palupi, N.S., dan Astawan, M. 1992. Metoda Kimia Biokimia dan Biologi dalam Evaluasi Nilai Gizi Pangan Olahan. Petunjuk Laboratorium. Dir Jen Pendidikan Tinggi. PAU Pangan dan Gizi. IPB. 89 pp.

Nurilmala, M. 2004. Kajian Potensi Tulang Ikan Keras (Teleostei) Sebagai Sumber Gelatin dan Analisis Karakteristiknya. Thesis. Sekolah Pasca Sarjana IPB. 89 pp.

Poppe, J. 1992. Gelatin. In Imeson, A. (ed.). Thickening and Gelling Agents for Food. Blackie Academic and Professional, London.

SIGMA. 2002. Biochemicals and Reagents. USA. 900 pp.
SNI 01-2332. 1991. Metode Pengujian Mikrobiologi Produk Perikanan : Penentuan Escherchia coli. Dewan Standardisasi Nasional, Jakarta.

SNI 01-2335. 1991. Metode Pengujian Mikrobiologi Produk Perikanan : Penentuan Salmonella. Dewan Standardisasi Nasional, Jakarta.

SNI 06-3735. 1995. Mutu dan Cara Uji Gelatin. Dewan Standardisasi Nasional, Jakarta.

Soekarto, S.T. dan Hubeis, M. 1991. Petunjuk Laboratorium Metode Penelitian Indrawi. Pusat Antar Universitas Pangan dan Gizi. Institut Pertanian Bogor.

Sopian, I. 2002. Analisis Sifat Fisik, Kimia dan Fungsional Gelatin yang Diekstrak dari Kulit dan Tulang Pari. Skripsi yang Tidak Dipublikasikan. Fakultas Teknologi Pertanian. Institut Pertanian Bogor. 98 pp.

Suryaningrum, T.D. dan Utomo, B.S.B. 2002. Petunjuk Analisa Rumput Laut dan Hasil Olahannya. Pusat Riset Pengolahan Produk dan Sosial ekonomi Perikanan dan Kelautan. Jakarta.

Tourtellote, P. 1980. Gelatin. Encyclopedia of Science and Technology. Mc. Graw Hill Book Co., New York. p. 93-94.

Utama, H. 1997. Gelatin yang bikin heboh. J. Halal LPPOM-MUI. 18: 10-12.

Winarno, F.G. 1991. Kimia Pangan dan Gizi. PT Gramedia Pustaka Utama. Jakarta.

Wiyono, V.S. 2001. Gelatin halal gelatin haram. J. Halal LPPOM-MUI. (36): 26-37.

Wainewright, F.W. 1977. Physical Tests for Gelatin and Gelatin Products. In Ward, A.G. and Courts, A. (eds.). The Science and Technology of Gelatin. Academic Press. p. 507-531.

Yoshimura,K., Terashima, M.M., Hozan, D., Ebato, T., Nomura, Y., Ishii, Y., and Shirai, K. 2000. Physical properties of shark gelatin compared with pig gelatin. J. Agric. Food. Chem. 48: 2023-2027. 